Témoigner Témoigner. Entre histoire et mémoire

Getuigen Revue pluridisciplinaire de la Fondation Auschwitz

$126 \mid 2018$

Questions sur l'avenir du travail de mémoire

\title{
Beyond the Era of Contemporary Witnesses
}

Postmemory and Intermediality Today

Au-delà de l'ère du témoin? Contours d'un sujet post-mémoriel

\section{Sébastien Fevry}

Translator. Elisabeth Tutschek

\section{(2) OpenEdition}

\section{Journals}

\section{Electronic version}

URL: https://journals.openedition.org/temoigner/7323

DOI: 10.4000/temoigner.7323

ISSN: 2506-6390

This article is a translation of:

Au-delà de l'ère du témoin ? Contours d'un sujet post-mémoriel - URL : https://

journals.openedition.org/temoigner/7293 [fr]

Publisher:

Éditions du Centre d'études et de documentation Mémoire d'Auschwitz, Éditions Kimé

Printed version

Date of publication: 2 April 2018

Number of pages: $91-101$

ISBN: 978-2-930953-06-9

ISSN: 2031-4183

Electronic reference

Sébastien Fevry, "Beyond the Era of Contemporary Witnesses", Témoigner. Entre histoire et mémoire [Online], 126 | 2018, Online since 24 January 2022, connection on 04 February 2022. URL: http:// journals.openedition.org/temoigner/7323 ; DOI: https://doi.org/10.4000/temoigner.7323 


\section{Beyond the Era of Contemporary Witnesses Postmemory and Intermediality Today}

\author{
$\rightarrow$ Sébastien Fevry \\ Translation from the German: \\ Elisabeth Tutschek
}

Professor Sébastien Fevry

(Belgium) teaches at the

Faculty of Communication

at the Catholic University

of Leuven (UCL). He is

the director of GIRCAM

(Interdisciplinary Research

Group on Cultures and

Arts in Transformation /

Groupe interdisciplinaire

de recherche sur les

cultures et les arts en

mouvements). He works

in the field of Memory

Studies and is mainly inter-

ested in the cinematic and

photographic representa-

tion of minorities. He is the

co-editor of a volume on

imagining the apocalypse

in cinema (2012) and

editor of Regards croisés

sur Incendies. Du theâtre

de Mouawad au cinema de

Villeneuve (2016). He pub-

lished numerous articles in

journals such as Image \&

Narrative, Cahiers Mémoire

et Politique, Espacetemps.

net, and Studies in French

Cinema

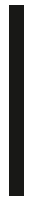

n times of the Internet and the emergence of digital culture, it is crucial to study the more or less radical changes that come along with the dynamics of appropriating memories of important past events. My hypothesis about this new cultural setting is that we witness the appareance of a novel kind of character these days: one who remembers, but who is neither a historian nor a witness, and whom I would like to call the "postmemory subject" for the time being. My paper will try to trace the outline of this postmemory subject. What are their methods of action and creativity? In what type of cinematographic and literary works do they appear? What is their specific relationship with the past? And, in particular, why does the postmemory subject so powerfully enter a cultural universe that is characterized by a dematerialization of images, an interdependence of media, and an increasingly free access to documents of the past?

To answer these questions, I will, first, point out the main features of our current period, before turning to carefully examine the concept of postmemory developed by the US researcher Marianne Hirsch. This information will help with establishing the profile of the postmemory subject and examining the dynamics of some artistic productions that have emerged from that posture of enunciation.

\section{A NEW LANDSCAPE OF MEMORY?}

Two essential features of the present sociocultural landscape have stimulated the emergence of new forms of memory or, at least, a particular way of referring to the past.

The first main feature can be identified as the advancing disappearance of contemporary witnesses of the $20^{\text {th }}$ century's most formative events, such as the Second World War and the Holocaust. There is no need to explicitly stress the fact that contemporary witnesses are dying one after another and that, in the future, occasions to speak with peope, who actually witnessed those events in person, will become rare. Even if testimonies were thouroughly recorded and archived, with the disappearance of contemporary witnesses, we loose the dialogical situation, which is typical for each testimony and which, as Paul Ricœur pointed out, above all, provided the opportunity to repeat statements and answer questions from the public (see Ricoeur 2000, 204-208). 
Besides - physical disappearance of contemporary witnesses apart - the question should be asked if it is not a whole social model of memory which is little by little getting lost here. Schematically considered, two distinct major periods of memory succeeded one another in the second part of the $20^{\text {th }}$ century: the era of archives, with the role of the historian at its centre as well as a limited and regulated access to traces of the past, and the era of contemporary witness, which occurs as of the 1970 and peaks with Claude Lanzmann's film Shoah in 1985. In her famous work L’Ère du témoin (The Era of the Witness), Annette Wieviorka specifies that testimonies no du tem in (The Erafthe Witness), An longer exclusively correspond to a simple inner need but that they become "a veritable social cooperative [that] transforms the witness into an apostle and prophet (Wieviorka 2006, 135-136). If we believe what some researchers say, though, this era should come to an end soon. In Agents of Liberation. Holocaust Memory in Contemporary Art and Documentary Film (2016), the cultural scholar Zoltán Kékesi stresses that a return to documents and archive material has happened since the beginning of the $21^{\text {st }}$ century, at least as regards the remembrance of the murders of Jews. ${ }^{1} \mathrm{He}$ draws upon Georges Didi-Hubermann's book Images malgré tout (Images in Spite of All, 2003), for example, which focuses on photographs that were taken inside extermination camps.

In my opinion, we should watch out for overly linear periodizations. Rather than seeing them as chronological consecutive periods of memory, I want to argue that these large periodizations are partly intertwined. The claim that we are leaving the era of contemporary witnesses, for example, seems wrong to me since testimonie continue to be highly relevant in our media spaces. Let us just think of the testimonies of Gulf war veterans, the accounts of survivors of the Paris or Brussels attack or, similarly, the reports on what is ts of survivors of the Paris or Brussels attacks remain an important method to understand the past. Earlier events that happened three or four generations back, however, require new practices of transfer. Memories are no longer by definition passed on through the intervention of a living witness, who reports their past experiences to third parties.

As a second main feature of the present landscape of memory, we must consider what the sociologist Rény Rieffel called the "digital revolution" (Riefel 2014) revolution based on important technological change and characterized by a digitalization of content as well as the boom of the Internet and social networks. This revolution is, as Rieffel stresses, not simply technological but also cultural, in the sense that it deeply affects various areas of people's activities. Because of the crumbling of traditional walls between creators and spectators, everybody can now produce and distribute cultural content.

This digital revolution is not without consequences for the practices of memory. First, access to online archives containing letters, photographs and, recently, films increases. These archives are not always centralized in databases; they may be situated on private pages or linked to personal blogs, so that we are faced with be sive tographs found on flea markets. They are selected on the basis of aesthetic criteria or with the objective of having purchasers indulge in nostalgias about a past that they did not actually witness themselves.

When combining this point with the first key feature (the advancing disappearance of contemporary witnesses), we see that an impressive amount of pictures and documents of thepast

- though in a sense

deprived of memse

deprived of memory - circulate on the web. These pictures testify to a past time or refer to an event long ago, but there are no contemporary witnesses any more to comment on them. They are orphaned pictures, anonymous documents, dissocidocissociated from any beare

assign a specific story to them. To the progressive but inevitable disappearance of contemporary witnesses now corresponds a growing circulation of anonymous documents. These documents render the absence of those people, who would be able to explain them, even more palpable. On this level, we can potentially already see a hint of one of the characteristics of the postmemory subjects that I will return to later and which consists of giving back meaning to those picures, reintegrating them in a true dynamics of memory.

The second consequence of the digital revolution is the fact that blogs and other rivate prive " (Allad2011) Social individe closely linked to aserch for he sel, from now on, everyone can go about the study of their own history and their own memories without necessarily associating them to an institutionalized memory. This has already been substantiated by the development of pages and forums that deal with genealogical researches. The "I" is at the centre and the quest for memory often takes on autobiographic traits, as if it were necessary to reconstruct the history of one's own family in an ever accelerating society that is prone to dismiss traditional orientation and parameters.

\section{THE CONCEPT OF POSTMEMORY}

In this simultaneously cultural, technological, and social context, the concept of postmemory, developed by Marianne Hirsch, comes into play. In The Generation of
Pictures for sale on like family photos. The page www.originalsnapshop.com, for example, offers pho- 
Postmemory. Writing and Visual Culture After the Holocaust (2012), Hirsch define postmemory, first of all, as the relation of the second generation's children to the historical traumas that their parents have witnessed. The author mainly focuses on the difficulty of memory transfer for those children whose parents or grandparents have experienced the camps during World War II. According to Hirsch, the children of the second generation are shaped by the close proximity to pain and suffering and haunted by stories and memories that took place before they were born (see also Rosa 2010)

Strictly speaking, postmemory is not proper memory at all since the members of the second and third generations live in the shadow of an event they did not witness themselves and which, as a result, they cannot actually remember. Hirsch nevertheless prefers the term "memory" to describe their affective relation to the past and to explain the dynamics of memory transfer that these children try to retrieve when faced with a family history characterized by silence and death.

Hirsch later broadens her definition by introducing the concept of "affiliative memory", which includes postmemorial postures that go beyond the parent-child relationship. Postmemory is then about understanding the commitment of a generation with regards to events witnessed by previous generations, for example, when appropriate a historical event that is not necessarily part of their family sphere.

Whether postmemory is understood in a narrow or broad sense, it seems logical that Hirsch uses the expression "post" as the generational commitment happens after their parents' memory, after the trauma of the previous generation. This first approach already shows how postmemory constructs a relevant set of social memory practices, in which, by definition, the past is no longer mediatized with the help of first-generation witnesses.

Moreover, postmemory does not only refer to the commitment of a generation, but also to a certain way of representing, or staging, past events. Hirsch extensively analyses postmemory works like the comic book Maus by Art Spiegelman (1986 and 1991 for the second volume) or the text Austerlitz (2001) by W. G. Sebald. Postof cultural productions that reflect this generational commitment. According to Hirsch, the specificity of postmemory work is the imaginative investment that fill the blank spots in family memory. It is not merely about remembering, but about using imagination to connect with a past that was not experienced at first hand and that is characterized by ellipses and silence. One of the most frequent strategies of postmemory work is to draw from other sources of memory - for example, to compensate for the lack of private photos by appropriating official images, which display traces of the same traumatic event. When Art Spiegelmann evokes in Maus his father's liberation from the extermination camps, he resorts to a press photo that has gone down in collective memory to compenste for the missing picture. With has his drawing, he transfers a picture from collective cultural memory to include it in
his own family album.

\section{FIRST APPROACHES TO THE POSTMEMORY SUBJECT}

This short presentation already shows how important it will be to consider the issue of postmemory when thinking about contemporary developments of memory. At the same time, it seems to me that Hirsch's work could benefit from an exploration of the "posture of enunciation" that underlies postmemory production. That is why I would like to "bend" Hirsch's work a bit by carving out the silhouette of the postmemory subject. This subject is a subject of enunciation - notareal person but postn I won, but rather a process of subjectivation and expression, which can be identified in various cultural productions. The postmemory subject is not limited to a specific medium,
but occurs with common traits in films, comics, and novels. To refs with common traits in films, comics, and novels.

To refine this hypothesis, the rest of my paper will concentrate on three specific productions. I will deal with the comic Palacinche. Histoire d'une exilée [Palacinche, Story of an Exile] (2012) by Caterina Sansone and Alessandro Tota, the "research novel" Les gens dans l'enveloppe [The People in the Envelope] (2015) by Isabelle Monnin as well as the film No pasarán, album souvenir [No pasarán, Souvenir Album] (2003) by Henri-François Imbert.

In Palacinche, the reader accompanies the author Caterina Sansone and the illustrator Alessandro Tota on a journey. Caterina takes the same path a her illustrator Ales the reader aco Tota on a joune Caterina takes parents once did, but in expelled from Croatia at the end of World War I, the author's parents were living in Italian refugee camps together with their grandparents and other family members for twelve years. Les gens dans l'enveloppe is a book-object (livre-objet) by Isabelle Monnin. In 2012 the author buys a batch of 250 photographs online, which come from a family unknown to her. At first, she writes a novel based on these photos; then, in the second part of the work, she travels to the region where the photos
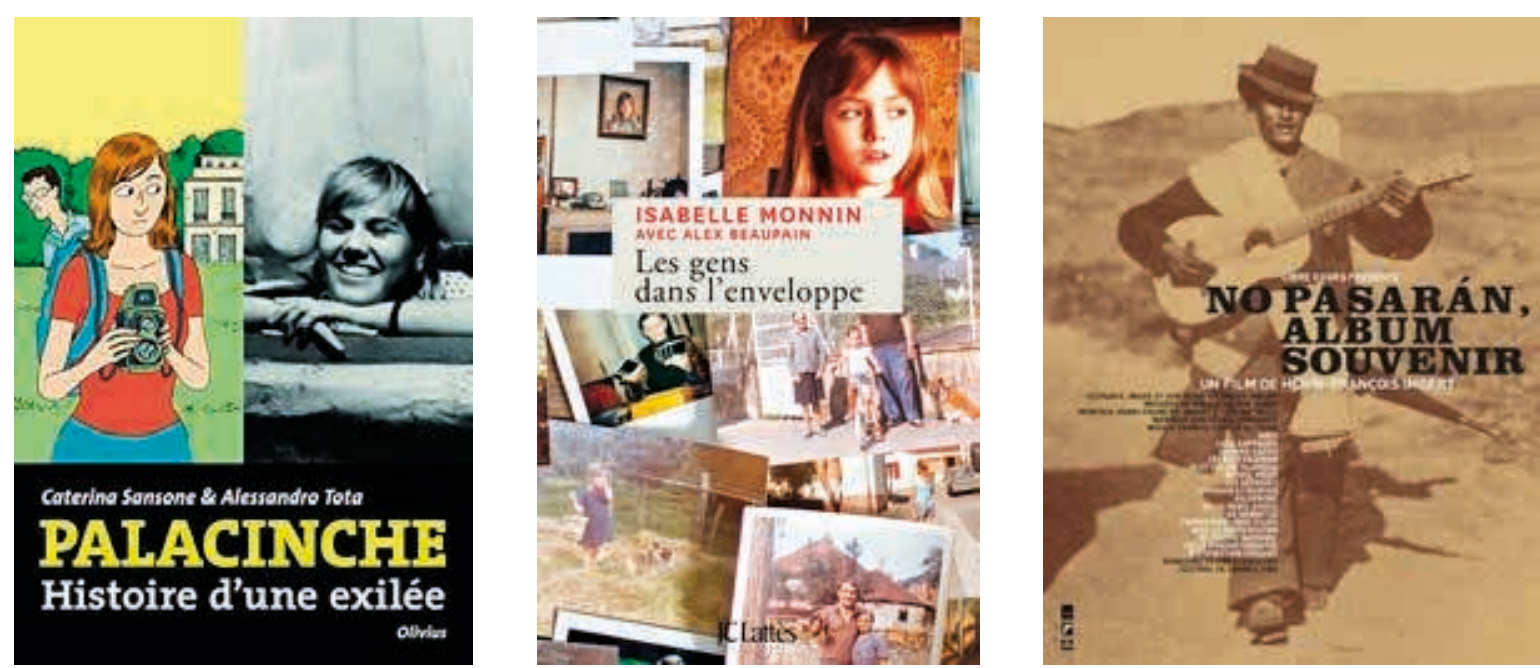
had been taken to retrieve the traces of these people and confront her imagination with reality. Finally, in No pasarán, album souvenir, Henri-François Imbert tackles the story of Spanish Republicans who fled to France after the Falangists' victory in 1939. These expats are being locked up in concentration camps in the South of France. Later on, some of them are surrendered to the Germans and taken to the Austrian concentration camp Mauthausen. The film is based on a series of picture postcards that were produced at the time of the events - the filmmake had found them in his grandparents' loft. The story presents itself like a quest, The of pictures to trace the route of the Spanish refugees.

Even though these memory productions differ in their media form as well as in content, all three nevertheless set the scene for a postmemory subject with identical characteristics.

\section{SUBJECT: THE "INVESTIGATING SELF"}

The first characteristic of the postmemory subject is that it defines itself as an "investigating self" The emblematic postmemory hero is an "ego", it is a person who stages themselves, a writer-narrator who investigates their own history or who stage someone else's, if it seems pressing and necessary for them to do so. At this point, the socio-cultural context we mentioned earlier comes into play, that is to say, we witness the emergence of an expressive contemporary individualism in which the quest for memory is prompted by a process of identity seeking.

In No pasarán, album souvenir, the filmmaker Henri-François Imbert goes on a trip in search of forgotten postcards and portrays, by the use of voice-over, the progress of his quest for memory, which leads him to a junk dealer in Narbonne and a former Catalan expat. The same kind of quest informs both Les gens dans l'enveloppe and the comic Palacinche. Each time, the authors take centre stage and begin investigations to disclose secrets of the recent past that are concealed by official memories. The scriptwriter's choice is similar to the historian's logic of scientific inquiery as developed by Carlo Ginzburg: it is a matter of including in the narrative the progress, limits, and efforts that occur during investigations. ${ }^{3}$

The investigation in the three productions studied here bears strong similarities The investigation in the three productions studied here bears strong similarities
not so much to the historian's work, but rather to journalistic research in its social not so much to the historian's work, but rather to journalistic research in its social
and cultural aspects: the reporter-journalist is staged as a main character, the chosen medium is the interview, and the research includes collecting documents and travelling to various sites. Moreover, the scene in which the two authors of Palacinche try to convince a publisher to promote their comic strip project seems to take place in the office of the editor-in-chief of a daily newspaper.

The biography of the authors is another element that confirms the connection etween the postnemory subject and journalism. Before she pursued witing belle Monnin worked as a journalist at the Nouvel Observateur for a long time. In Les gens dans l'enveloppe she uses her journalistic experience to retrieve traces of the unidentified people in the pictures she bought online. The approach chosen in Palacinche by Caterina Sansone and Alessandro Tota also resembles that of a journalistic investigation. Before Sansone started the comic strip project - which, by the way, some call a "comic report"- she worked as a photojournalist for the agency Magnum. These examples show that some of the authors working in the field of postmemory are not necessarily visual artists or filmmakers, but people that initially made a career in the press.

From a strict "memory" perspective, we must stress the intention behind this kind of approach. The postmemory subject's actions are determined by an awareness of and wish to shed light on certain dark spots in History: the postmemory subject is not subject to the caprices of involuntary remembrance or sudden recollections that would otherwise dictate which path to take. Once again, it is rather a matter of consciously and determinedly appropriating fragments of a past that was not experienced by oneself, but becomes nevertheless an important part of one's search for identity.

MODE OF OPERATION: ENGAGING WITH IMAGES

The second constituent characteristic of the postmemory subject is its mode of operation - engaging with images. The "investigating self" consults documents deprived of memory - a fact that points to another important characteristic of our

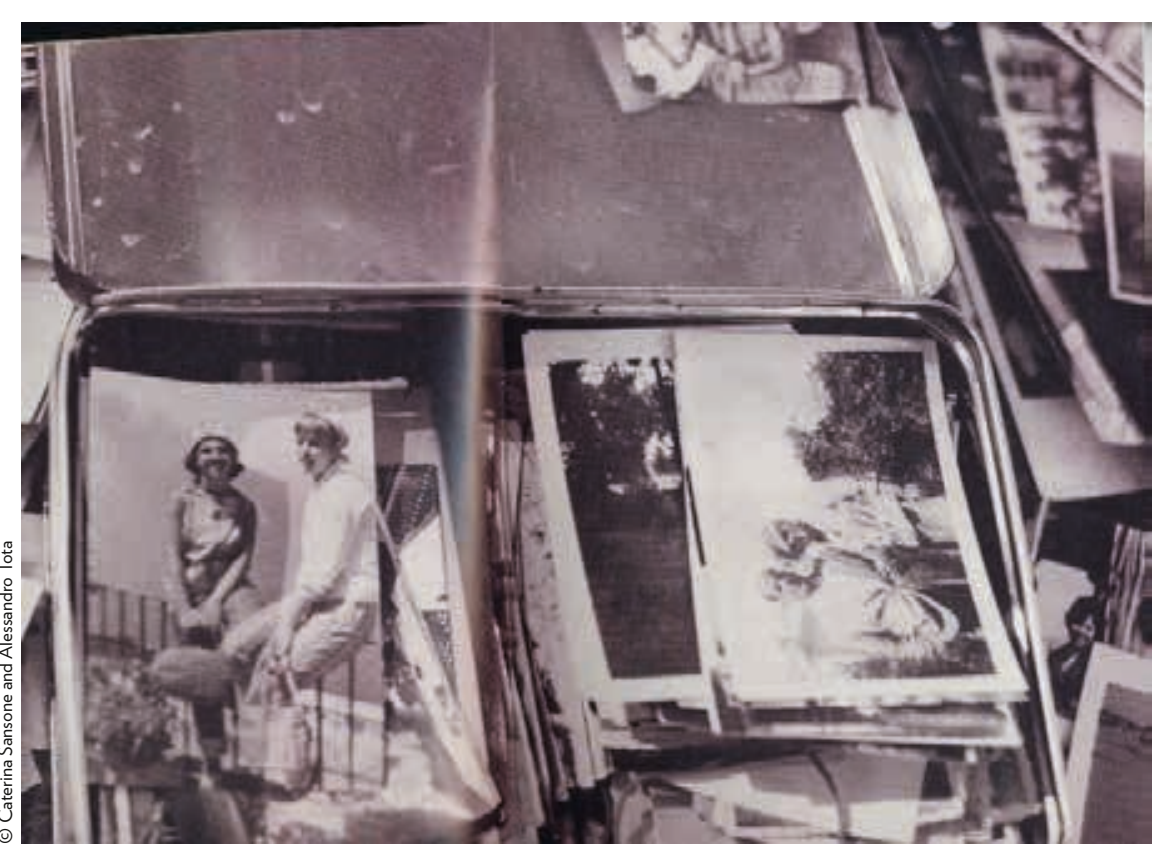


contemporary landscape of memory. Coming along with the advent of digital culture is a continuously increasing volume of images of the past that are not necessarily tied to a bearer of memory and that circulate on the Internet. They include photographs. videos, and Super 8 films, which have been removed from the social context from which they have resulted in the first place. It is those images-without-witnesses that the postmemory subject inquires into.

No pasarán, album souvenir starts with the filmmaker's discovery of an incomplete series of picture postcards in his grandparents' loft The pictures broach the es broach the issue of the arrival of Spanish refugees in the South of France - an event nobody had ever told him about, until then. Isabelle Monnings novel Les gens dans l'enveloppe starts with her analysis of anonymous photographs she bought online. She has no idea who those people are, there is no link to her own family history, but the writer is interested in them because it seems to her as if these photos could replace the pictures of her own family (Monnin 2015, 180). Lastly, in Palacinche, the narrative is triggered by the discovery of a batch of photos in a tin can. These photographs give the author access to a past that she knows nothing about but "a few anecdotes, scattered here and there" (Sansone \& Tota 2012, 14; translation ET).

This engagement with already existing traces of the past explains why postmemory works are oftentimes intermedial-pieces of work in which different kinds of media works a coexist: novel and photography in the case of Isabelle Monnin, drawing and photography in the case of Palacinche, or even cinema and photography like in Henri-Françoi Imbert's film. Yet, this intermediality also shows on another level. Usually, postmemory works do not content themselves with merely incorporating visual document from the past, but rather re-interpret the traditional media that are generally used to exhibit family memories. For example, the cover of Les gens dans l'enveloppe takes up an aesthetics of chaos while certain visual constructions in Palacinche and No pasarán, album souvenir remind of photo albums. By means of these aesthetic choices, the authors try to reiterate the practices that normally allow the appropriation of family memories. It seems as if they want to give these orphaned pictures a second chance by including them once again in practices of memory transfer.

This is how we can understand the postmemory subject's method and mode of action. They oftentimes aim at completing a series of pictures, putting the chaotic state of the photographs found in a tin can back in order. Henri-François Imbert's project is about completing the series of postcards and retrieving the places where those pictures had been taken. Caterina Sansone and Alessandro Tota apply the same principle, when they contrast old black and white photographs with colour pictures of the same places today. And in Les gens dans l'enveloppe, Isabelle Monnin tries to imagine the lives of people in the anonymous photos she bought on eBay. The author wonders, "which journey those pictures must have made to end up with me, who has so few photos of my own family. Why were they entrusted to me?" (Monnin 2015, 180: translation ET)

In each of the cases the "investigating self" appears as a collector of images - as someone, who brings together pictures from the past to put them in a new, meaning- ful context. It is a matter of completing and reconstituting an image that was taken in another context, of letting it speak and, more generally, writing it into one's own quest for memory and one's own history.

\section{METHOD OF REMEMBRANCE: RECOGNITION}

This mode of operation activates a specific manner of remembrance, in which the remembering subject appropriates a family history that is not their own. The "investigating self" does not remember in the literal sense, since it has not experi"investigating self" does not remember in the literal sense, since it has not experienced the events of which it speaks. There is no real memory work going on. Then again, it seems to be enough to reorganize and reconstruct images of the past to produce recognition effects that can come very close to a process of remembrance.

The search of the "investigating self" is indeed marked by the notion of recognition, which is described as an adventure of sensing by the philosopher Edward Casey in his phenomenological approach to memory - that is to say, elements dating from the past are being recognized in the present (see Casey 2000, 122-140). In La mémoire, l'histoire, l'oubli (Memory, History, Forgetting), Paul Ricœur likewise stresses the act of recognizing as being at the centre of each process of remembrance:

I consider recognition to be the small miracle of memory. And as a miracle, it can also fail to occur. But when it does take place, in thumbing through a photo album, or in the unexpected encounter with a familiar person, or in the silent evocation of a bein who is absent or gone forever, the cry escapes: "That is her! That is him!" And the same greeting accompanies step by step, with less lively colours, an event recollected, a know-how retrieved, a state of affairs once again raised to the level of "recognition" Every act of memory is thus summed up in recognition. (Ricoeur 2004, 494-495)

On this philosophical basis, recognition can be considered the culmination of the postmemory subject's quest. In Palacinche, Caterina Sansone finds the places that were photographed 50 years earlier. She recognizes in the present time the that were phor places phote place when the author discovers odd parallels between the real lives of the people in the photographs and the literary, imaginative work that she created on the basis of precisely those photo

A sequence in No pasarán, album souvenir illustrates this phenomenon of recognition as well. Imbert repeatedly starts with a postcard to, then, find the place in the picture and see what it looks like today. At the discovery of the former camp Amélieles-Bains, which serves as a camping ground today, a tracking shot starts off the scene, which shows the hilly landscape around that place. As soon as the filmmaker arrives at the former prison, he turns away from the camera and brings an old picture postcard f the camp to the hect of the cortray the place as it is today. This play between two images - one of the past and one of the
present - produces a feeling of recognition. Both the filmmaker and the audience can (4) For further details on the
film and on the process of
recognizing, see Fevry 2015. 
now say: "Yes, it happened right there. I recognize the place that I saw on the postcard before."

In Palacinche also, recognition takes place because of the complementary use of various media sources. Two different pictures that were taken in different periods of time are linked to a single identification point and, in this way, enable the viewer to recognize the same object, the same place or the same person through the multiple prisms of a visual kaleidoscope. The moment of recognition thus arises from the images that have come to echo the subject's own current situation.

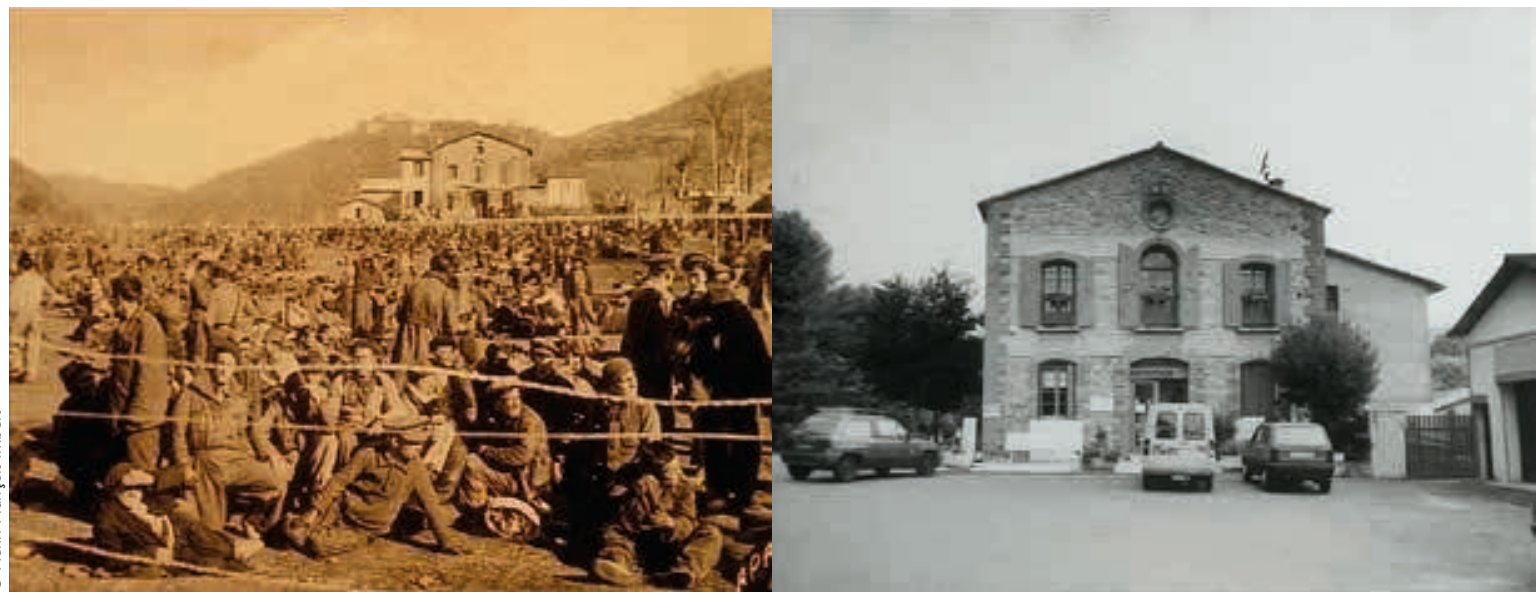

Screen shots from

Sopasarán to choose from and rank them. If there is a danger of forgetting, it is the result of an inability to establish a solid anchorage from this mass of documents that could help us understand our own present.

Paul Ricœur distinguishes forgetting through erasure of traces from "backup forgetting", "reserve of forgetting": "On the one hand, forgetting frightens us. Are we not doomed to forget everything? On the other hand, we welcome that little feeling of happiness that befalls us when a fragment of the past resurfaces, snatched from oblivion, as they say" (Ricoeur 2000,45; translation ET) It is exactly against fo " this "reserve of frosting" that the postmemory subject is fighting. It reactivates certain traces while neglecting others, makes "orphaned" images enter into dialog with one another, and is on a constant pursuit of that little, fragile, and volatile feeling of happiness triggered by the moment of recognition when an image appears that gets the dynamics of memory going again.
WORKS CITED

- Allard, Laurence, "Express yourself 2.o! Blogs, pages perso, l'expressivisme generalise', in Eric Macé \& Éric Maigret (eds.). Penser les médiacultures. Nouvelles pratiques et nouvelles approches d

My paper traced the outline of a postmemory subject that is neither a witness nor an archivist. This novel phenomenon could not have emerged as such outside of the contemporary context, which is at once characterized by the advancing disappearance of contemporary witnesses of the $20^{\text {th }}$ century's major events and a steadily increasing number of memory-deprived images that circulate. In this sense, the postmemory subject's ultimate task is to interrupt the flow of images, activate one of the pictures, and integrate it in a dynamics of memory that can trigger the small miracle of recognition.

Besides, the perhaps most relevant twist of our times occurs at this level. The question could indeed be: what is the postmemory subject actually fighting? Oblivion, of course, and the gradual disappearance of memories and of previous generations. The oblivion that the postmodern subject is opposing is less about forgetting as a The oblinith as a result of the shortage documents from the past, but rather of their abundance.
- Besson, Rémy, Zoltán Kékesi, Agents of Liberation. Holocaust Memory rendus, 2016, http://lectures.revues.org/20143 (accessed 4 January 2017).

- Casey, Edward S., Remembering: a phenomenological study [1987].

University Press, 2000 Namembering in the Cinema of Henri-François Imbert', Image

- Hirsch, Marianne, The Generation of Postmemory. Writing and Visual
Culture After the Holocaust, New York: Columbia University Press. 2012 - Monnin, Isabelle \& Alex Beaupain, Les gens dans lenveloppe. Roman,
- Fevry, Sébastien, Aesthetics of Recognition and Photofilmic Dynamics
Riceur Paul La mémoire Ihistoire loubli, Paris: Sevil, 2000 -.-., Memory, History, Forgetting, translated from the French by Kathleen - Rieffel, Rémy, Révolution numérique, révolution culturelle?, Paris.

- Rosa, Hartmut, Accéleration: une critique sociale du temps, Paris: La
Découverte. 2010 . - Sansone, Caterina \& Alessandro Tota, Palacinche. Histoire d'une exilée,
Paris: Olivius, 2012.

- Uhl, Magali, 'Les montages narratifs de lintime entre mémoire
et fiction. De Stories we Tell a V Vies possibles et imaginaires', in Id. et fiction. De Stories we Tell à Vies possibles et imaginaires, in Id.
(ed.), Les récits visuels de soi. Mises en récit artistiques et nouvelles
scenogarahiques de lintime, Paris: Presses universitaires de Paris Ouest. scénographiques do

- Wieviorka, Annette, Era of the Witness, translated from the French by
Jared Stark Ithaca: COronll Universisy Press 2006 . 